\title{
CUTANEOUS ASTHENIA IN ONE DOG
}

\author{
F. JELINEK ${ }^{1}$, J. KARBAN \\ 'Veterinary Histopathological Laboratory, Prague \\ Veterinary Clinic, Rychnov nad Kněžnou
}

Received April 6, 1998

Accepted June 5, 1998

\begin{abstract}
Jelinek F., J. Karban: Cutaneous Asthenia in One Dog. Acta vet. Brno 1998, 67: 109-113.

Cutaneous asthenia was diagnosed in a 6-month-old bitch of the Fila Brasiliero breed. The animal was also suffering from juvenile poyderma, which was successfully cured. Owing to poor prognosis of the cutaneous asthenia the dog was euthanatized at 13 months of age. No pathological lesions were observed in the animal's internal organs. Histology of the skin revealed a loose arrangement of the collagen connective tissue in the dermis. The collagen fibres were of variable thickness, tortuous and fragmented. The thick fibres consisted of a homogeneous axial part, which contained neutral proteoglycans, and a fibrillar periphery. These peripheral fibrils were composed of acid proteoglycans, contained vimentin and bound ConA, PNA, RCA, SBA and WGA lectins. Elastic fibres were absent. Considering the fact that the central zone of collagenous fibres in our case of cutaneous asthenia had the same structural and staining characteristics as normal fibres. our findings suggest that the maturation of these fibres proceeds from their axial segments towards the periphery. We assume that the pathogenesis of cutaneous asthenia consisted in retarded or arrested maturation of collagen fibres.
\end{abstract}

Cutaneous asthenia, dog, lecitin, histochemistry, proteoglycans

Cutaneous asthenia (Ehlers-Danlos syndrome, dermatosparaxis, cutis hyperplastica) is a hereditary congenital defect of dermal connective tissue. It is a rare disease, known in man but also occurring in cattle, sheep, dogs, cats, horses, rabbits, mink and pigs ( $\mathrm{Jubb}$ et al. 1992). The diagnosis is based on clinical signs as well as morphologic and biochemical abnormalities of dermal collagenous tissue.

The clinical signs are hyperextensibility and a decrease of tensile strength of the skin. The skin may be stretched out many centimetres and in some regions of the body it is arranged in folds. The decreased tensile strength may result in lacerations even from minimal trauma (Gross et al. 1992; Yager and Wilcock 1994).

The histological appearance is not typical. In some cases it may be conspicuous, in others not. In humans, several metabolic abnormalities have been identified using biochemical methods. In animals, defects in procollagen $\mathrm{N}$-peptidase and alteration of the alpha-chain of type 1 procollagen have been recognized (Patters on and Minor 1977).

This is a case report of cutaneous asthenia in a dog. Clinical and histological examination were carried out along with immunohistochemistry and lectin histochemistry.

\section{Clinical case history}

The dog, a female purebred striped Fila Brasiliero, was purchased at six months of age. At that time it had some poorly healed skin lesions localized on the neck and the right side of

Address for correspondence:

Doc. MVDr. František Jelinek, CSc.

Veterinárni histopatologická laboratoř

Sojovická 16

19700 Praha 9 - Kbely. Czech Republic

Phone/fax: + 42() 2-850)1765 
the back. In general, the dog was shar-pei-like in appearance especially owing to abundant foldings of the skin and pouch-like formations in the carpal and tarsal regions. The animal suffered from subcutaneous effusions, haemorrhagic or serous in appearance and localized mainly in tarsal and carpal regions, at olecranon ulnae and elsewhere. The dog also suffered from many repeated skin lacerations caused by any minimal trauma. Healing of the skin wounds was slow. usually taking 14 and more days. Sutures were often piercing through dermal tissue. The skin on the trunk could be stretched out many centimetres (Plate V., Fig.1). Index of extensibility (Ie) was counted using the formula:

$$
\text { Ie }=\frac{\text { length of outstretched skinfold on the back } \times 100(\%)}{\text { length of body of the animal }}
$$

The le value was determined as $19.72 \%$ (normal value being below $14 \%$ ).

The disease was diagnosed as cutaneous asthenia.

Apart from this disease the dog suffered from juvenile pyoderma, clinically manifested by poor nutritional state, dull coat, easily extractable hairs and malodour of the animal. There were excoriations, deep linear lesions, granulations and epithelization of the skin lesions. In the auditory canal signs of inflammation were found. Both microscopical examination of skin scrape digested with $\mathrm{KOH}$ and trichoscopy were negative, DiffQuick-stained pustule smears revealed degenerative neutrophils and cocci and Malassezia canis was identified in a smear from the auditory canal. Haematological examination and serum chemistry did not yield any pathological findings. The juvenile pyoderma was successfully cured by means of bath in a shampoo with sulphur supplement (Perilacin Spofa), and local treatment of the skin lesions with a solution of potassium permanganicum and Iruxol Mono (Knoll AG). Otitis externa was successfully treated with Surolan (Janssen Pharm).

In spite of this treatment the animal was euthanatized at the age of 13 months by $T 61$ administered i.v. because of poor prognosis of skin asthenia. Immediately after death the main internal organs and skin were sampled for histopathological examination. The samples were fixed in $10 \%$ neutral formalin and submitted to Veterinary Histopathological Laboratory, Prague.

\section{Materials and Methods}

\section{Histopathological examination}

The samples of internal organs (lung, spleen, liver, kidney and lymph nodes) and skin were processed by the common paraffin technique and histological slices were stained with haematoxylin and eosin. Furthermore, skin samples from this dog and control skin specimens of a healthy dog, killed in a car accident were stained with alcian blue pH 2.5 + PAS. aldehyde-fuchsin + orcein + light green, and staining after Giemsa was done as well.

Immunohistochemistry consisted of demonstration of vimentin by means of DAKO antibody.

Lectin histochemistry: binding of concanavaline A, peanut agglutinin, Ricinus communis agglutinin 120, soybean agglutinin and wheat germ agglutinin was tested. Binding specificities of these lectins are indicated in Table 1. All of the lectins were products of LECTINOLA Prague, Czech Republic. They were labelled with peroxidase.

Both immuno- and lectin histochemistry were performed by a common peroxidase method. In short: Deparaffination (xylene, acetone, graded ethanol), block of the tissue peroxidase by $3 \% \mathrm{H}_{2} \mathrm{O}_{2}$ with sodium azide. For lectin-histochemistry, the slices were digested with $1 \%$ trypsin Spofa $+1 \%$ calcium chloride in PBS. Nonspecific protein binding was blocked with $1 \%$ bovine albumin in PBS. Binding of primary antibody proceeded for $60 \mathrm{~min}$ at room temperature in a wet chamber. Anti-mouse globulin labelled with peroxidase SEVAC (JSC, Prague, Czech Republic) was used as a secondary antibody for vimentin detection. The DAB Chromogen System, IMMUNOTECH, France, was used for visualization of the reactions (10 $\mathrm{min}$ at room temperature). Counterstaining with haematoxylin, dehydration and mounting in Entellan Merck followed. 
Table 1

Binding specificity of lectins

\begin{tabular}{|lc|l|}
\hline Name of lectin & & Binding specificity \\
\hline Concanavaline A & (ConA) & mannose, glucose \\
Helix pomatia agglutinin & (HPA) & N-acetyl-D-galactosamine \\
Lens culinaris agglutinin & (LCA) & alfa-D-mannose \\
Peanut agglutinin & (PNA) & beta-D-gal-N-acetylgalactosamine \\
Soybean agglutinin & (SBA) & N-acety-D-galactosamine \\
Wheat germ agglutinin & (WGA) & N-acetyl-D-glucosamine \\
& & sialic acid \\
\hline
\end{tabular}

\section{Results}

Postmortem examination: No pathological lesions were observed in internal organs collected for histological examination.

Histology of internal organs: No pathological lesions were diagnosed in the lung, spleen, liver and kidneys. Signs of mild chronic antigenic stimulation were observed in subcutaneous lymph nodes.

Histology of the skin: There was a mild hyperplasia of the epidermis, mild atrophy of the sebaceous glands and suspect dilatation of the apocrine (paratrichial) glands. Collagenous connective tissue was looser than in the control animal. The fibres were of variable thickness, tortuous and fragmented (Plate V., Fig. 2). The thick fibres were not homogenous. Fibrillar or fragmented structures were visible at their periphery, while their axial part was homogenous. Fibrocytes were more numerous than in control skin.

Alcian blue 2.5 + PAS. Collagen in the control skin and thin fibres in cutaneous asthenia stained blue owing to their content of acid proteoglycans. The central part of the thick fibres was PAS-positive (because of content of neutral proteoglycans) and numerous fibrils containing acid proteoglycans were present in the periphery (Plate V., Fig. 3). The basal membrane of the epidermis was predominantly wavy or corrugated, serrated here and there. The junction between the epidermis and dermis consisted of a dense network of very thin fibres composed of acid proteoglycans. In healed lacerations. these fibrils were arranged perpendicular to the basement mebrane.

Staining with aldehyde-fuchsin, orcein and light green revealed a reduction or total absence of elastic fibers in the dermis. The thick collagen fibres stained green at the periphery, and their central part was stained yellow by orcein. In the control skin the elastic fibers form a loose network around the hair follicles, in the superficial corium and especially in the dermo-epidermal junction. Collagen fibres in the dermis were green.

Immunohistochemistry for vimentin revealed positivity of thin connective fibers and in periphery of the thick collagen fibres. This positivity was very similar to that obtained by staining with $\mathrm{AB} 2.5+$ PAS. The centers of the thick fibres were negative. Vimentin positive were also fibrocytes and fibroblasts in the dermis, in the epithelium of hair follicles and in the epidermis. In the control skin the collagen fibres were negative but remaining positivities were the same as in cutaneous asthenia (Plate VI., Fig. 4 and 5).

Binding of the employed lectins (ConA, PNA, RCA, SBA. WGA) followed a similar pattern as the vimentin positivities. All connective fibres in the dermis and in the subcutaneous tissue were strongly positive. The thick fibres displayed strong positivity in 
the superficial (peripheral) zone - positive were both the thin fibrils and granular material. Lectins did not bind to the central (axial) part of these fibres. Lectin histochemistry also revealed that some of the thick fibres were composed of bundles of fibres. Control skin showed slight lectin positivities on the surface of collagen fibres (Plate VI.. Fig. 6 and 7).

\section{Discussion}

Both from the clinical and pathological points of view. the case of cutaneous asthenia described above is in good agreement with reports in the literature (e.g. Gross et al. 1992; Jubb et al. 1992; Svoboda et al. 1994; Yager and Wilcock 1994: Niemand and Sutter 1996). In this disease disarrangement and fragmentation of collagenous fibres may be present in the dermis. Also fibres of varying diameter intervowen with widely spaced fibrillar bundles can be seen. In some cases, however. the histological picture may be inconspicuous. Yager and Wilcock (1994) describe defective collagen packing in some dogs as fragmented and unravelled or frayed collagenous bundles. Improper formation and packing of collagenous connective tissue is manifestation of a dominant form of heritability of cutaneous asthenia (Minor et al. 1987). By this criterion, our case would belong to this type. Unfortunately, it was not possible to obtain information about parents and littermates of our patient. In relevant literature we failed to find any characterization of cutaneous asthenia with recessive form of inheritance in dogs. However, in cats a recessive form of heritability is manifested by procollagen peptidase deficiency (Patterson and Minor 1977).

We did not find information concerning lectin histochemistry in cutaneous asthenia. The results of our examination showed that binding of lectins in collagen fibres was more intensive in the affected than in control skin. The reason for this was probably in disturbed structure of the fibres. Fibrils in the outer zone of thick fibres showed mostly positivity. Moreover, by means of lectin histochemistry we observed that some of the thick collagenous fibres were composed of bundles of fibres.

Using staining with alcian blue and PAS reaction we demonstrated that the same fibrils contained acid glycoproteins. Moreover the same fibrils also expressed vimentin. The axial, homogenous zone of the collagenous fibres did not bind lectins nor antibody to vimentin and contained neutral, PAS positive, glycoproteins. It seems that the maturation of collagenous fibres proceeds from the axial part to the periphery so that the axial zone of collagen fibers in cutaneous asthenia had the same structural and staining properties as normal fibres. We suppose that pathogenesis of the described cutaneous asthenia consists in a retarded or arrested maturation of the collagenous fibres. It is known (e.g. Banks 1993) that the secretory product of collagen producing cells is procollagen. This is enzymatically transformed into insoluble tropocollagen. The spontaneous self-assembly of tropocollagen into collagen follows the removal of the terminal peptides. The final step in the assembly process ensures that the tensile strength of collagen is established. This requires formation of intermolecular cross-linkeage that is achieved through oxidative deamination by lysyl oxidase.

In our opinion. another factor contributing to the diminished tensile strength of skin, apart from the alteration of collagenous connective tissue, was the absence of elastic fibres. These fibres are produced by fibroblasts and by smooth-muscle cells.

Determination of enzymatic deffect(s) responsible for the abnormal structure of collagen and for the absence of elastic fibres in the dermis was beyond our possibilities. Nevertheless. we hope that our results may be helpful in further study of the pathogenesis of cutaneous asthenia in dogs. 


\section{Kožní asthenie u psa}

Kožní asthenie byla klinicky diagnostikována u šestiměsiční feny brazilské fily. Kromě toho zviŕe trpělo juvenilní pyodermií, která byla úspěšně vyléčena. Vzhledem k nepřiznivé prognóze kožní astenie byl pes utracen ve věku 13 měsíců.

Postmortálně nebyly na vnitřních orgánech zjištěny žádné patologické změny. Histologické vyšetření kủže ukázalo řídce uspořádané kolagenní vazivo koria. Kolagenní vlákna byla rozdílné síly, byla pokroucená a fragmentována. Silná vlákna byla tvořena homogenní axiální částí jež obsahovala neutrální proteoglykany a fibrilární periferií. Periferní fibrily byly tvořeny kyselými proteoglykany, obsahovaly vimentin a vázaly se na ně lektiny ConA, PNA, SBA a WGA. Elastická vlákna nebyla přítomna. Vzhledem k tomu, že centrální oblasti kolagenních vláken měly stejné strukturální a barvicí vlastnosti jako normální kolagenní vlákna lze usuzovat, že vyzrávání kolagenních vláken probíhá od axiální části $\mathrm{k}$ periferii. Předpokládáme, že $\mathrm{v}$ tomto případě patogeneza kožní astenie spočívala $\mathrm{v}$ retardaci nebo přerušení maturace kolagenních vláken.

\section{Acknowledgements}

We are grateful to Dr. Tatiana Husáková and Dr. J. Homolka, Veterinary Clinic, Rychnov nad Kněžnou, for their cooperation in the clinical examination of the dog and to Head Physician Dr. P. Fiala, Department of Biochemistry, District Hospital, Rychnov nad Kněžnou, for the biochemical assays.

\section{References}

BANKS, W. J. 1993: Applied Veterinary Histology. Third Ed., pp. 68 - 81, Mosby, 527 p.

GROS, T. L., IHRKE, P., WALDER, E. 1993: Veterinary Dermatopathology, Mosby, 484 p.

JUBB, K. V. F., KENNEDY, P. C., PALMER, N. 1992: Pathology of Domestic Animals, Academic Press, Vol. 1, $780 \mathrm{p}$.

MINOR, R. R., WOOTOM, J. A. M., PROCKOP, D. J. 1987: Genetic disease of connective tissues in animals. Curr. Probl. Derm. 17, pp.199-215

NIEMAND. H. G., SUTTER, P. F. (Eds.) 1996: Klinická praxe u psů, H\&H Bratislava, 786 p.

PATTERSON, D. F., MINOR, R. R. 1977: Hereditary fragility and hyperextensibility of the skin of cats: a defect in collagen fibrillogenesis. Lab. Invest. 37: pp. 170-179

SVOBODA, M., DOUBEK, J., KONVALINOVÁ, J. NEČAS, A., RYBNÍCEK, J., SVOBODOVÁ, V. 1994: Dermatologie psa a kočky. 295-296 CAVMLZ Brno. 360 p.

YAGER, J. A., WILCOCK, B. P. 1994: Color Atlas and Text of Surgical Pathology of the Dog and Cat. Dermatopathology and Skin Tumors, Wolfe Publishing, 320 p. 


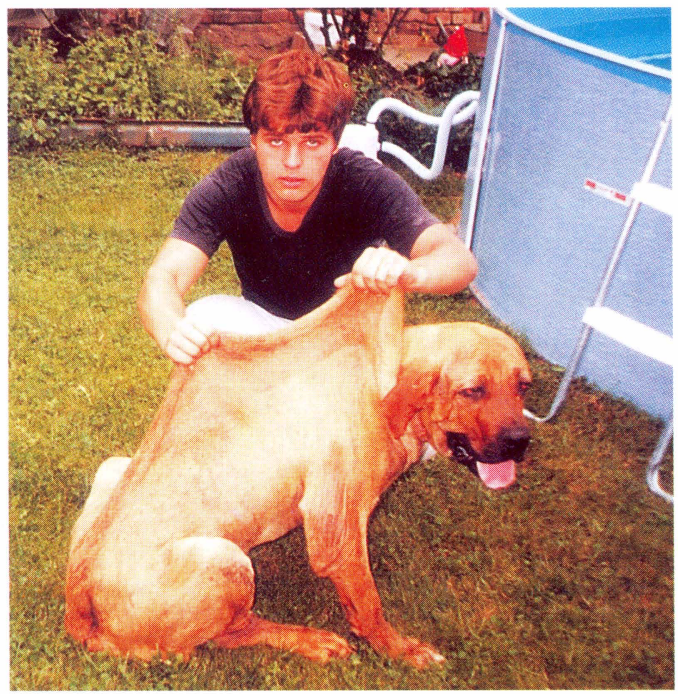

Fig. 1. Abundant fold formation on the back and pouch-like formation in the olecranon ulnae region.

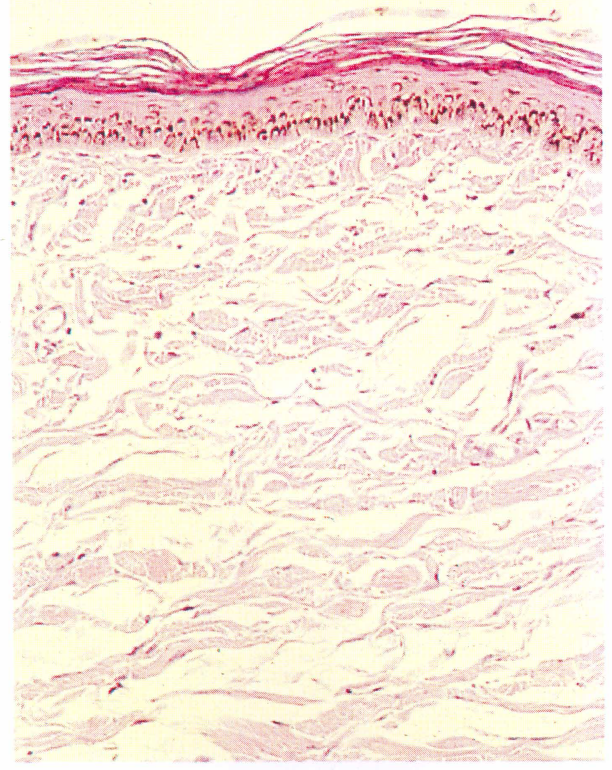

Fig. 2. Collagenous connective tissue is slightly looser and the fibres are of more variable thickeness than in normal skin. HE, original magnification: $\times 75$.

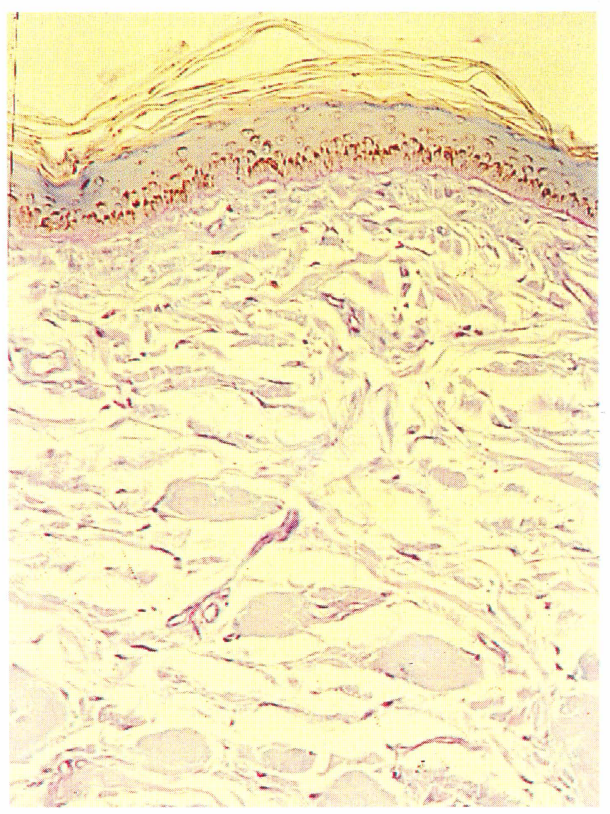

Fig. 3. Central part of the thick fibres is PAS-positive, at their periphery is a zone containing acid proteoglycans (blue color). PAS $+\mathrm{AB} 2.5$, original magnification: $\times 80$. 


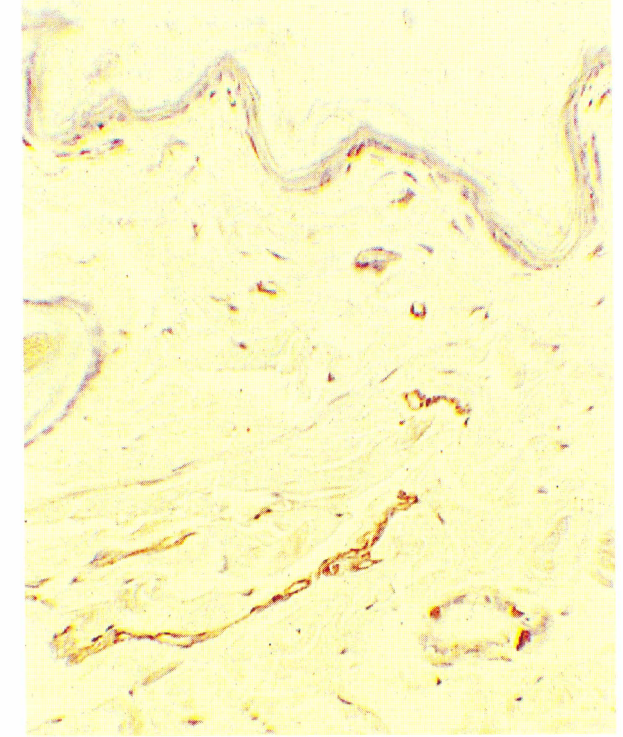

Fig. 4. Positivity of vimentin in the dermis of control skin is limited to fibrocytes. DAB, original magnification $\times 75$.

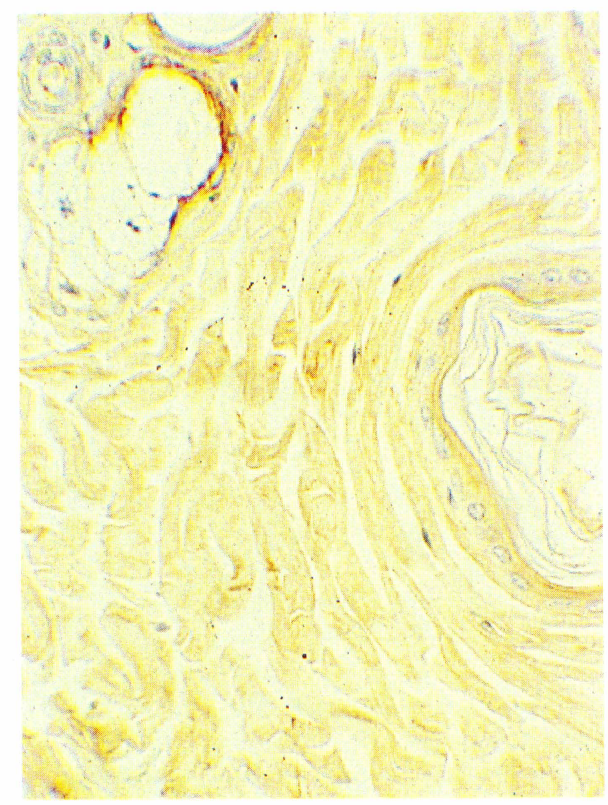

Fig. 6. Binding of PNA in control skin. Positivity of collagenous connective tissue is very weak. DAB, original magnification $\times 120$.

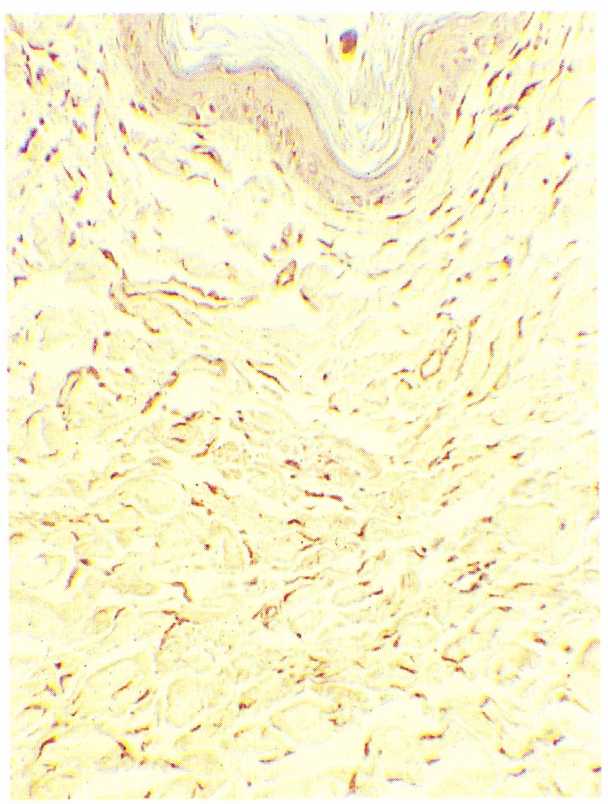

Fig. 5. Reaction for vimentin in the dermis of asthenia cutis. There is an increased number of positive fibrocytes and weak positivity in the fibres. DAB, original magnification $\times 75$.

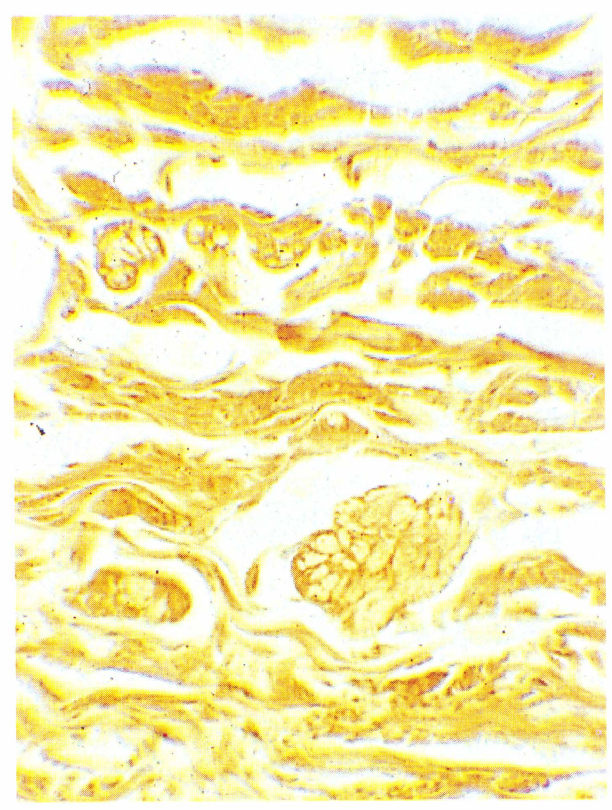

Fig. 7. Binding of PNA in asthenia cutis. There is a strong positivity at the periphery of collagenous fibres, some of the thick fibres are composed of bundles of fibres. DAB, original magnification $\times 120$. 